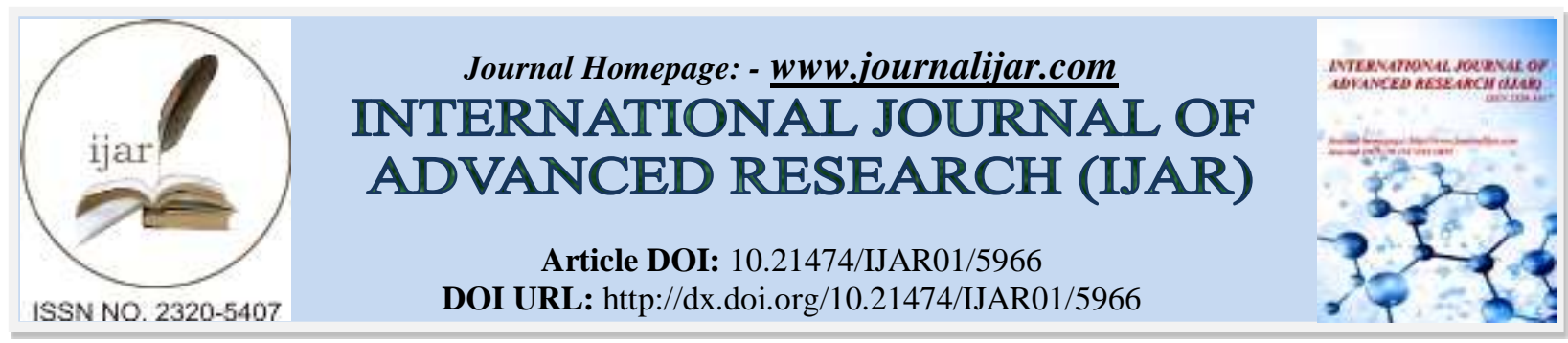

RESEARCH ARTICLE

\title{
NERVI OLFACTORIUS, OPTICUS AND OCTAVUS OF MALPOLON MOILENSIS.
}

Dakrory A. I $^{1,3}$, Abdel-Kader T. $\mathbf{G}^{2,3}$, Mahgoub A. $\mathrm{F}^{4}$ and Ali. R. $\mathrm{S}^{2}$.

1. Department of Zoology, Faculty of Science, Cairo University, Egypt.

2. Department of Zoology\&Entomology, Faculty of Science, Helwan University, Egypt.

3. Department of Biolgy, Faculty of Science, Taif University, KSA.

4. Department of Zoology, Faculty of Science, Sirt University, Lybia.

\section{Manuscript Info}

\section{Manuscript History}

Received: 04 October 2017

Final Accepted: 06 November 2017

Published: December 2017

\section{Key words:-}

nervus olfactorius- nervus opticusnervus octavus- Malpolon moilensis.

\begin{abstract}
The nervus olfactorius leaves the nasal cavity through the fenestra olfactorium advehens and enters the cranial cavity through its membranous wall i.e fenestra olfactorium evehens is absent. The nervus opticus enters the cranial cavity through the foramen orbitale magnum. The opposite nerves met together forming optic chiasma. The nervus octavus arises by a single root. The vestibular ganglion is located partially intracranially and partially in the foramen acousticum posterius. The ramus ampullaris anterior innervates the utricle and the anterior and lateral semicircular canals. The ramus ampullaris posterior innervates the lagena and the posterior semicircular canal. There is an independent saccular branch.
\end{abstract}

Copy Right, IJAR, 2017,. All rights reserved.

\section{Introduction:-}

The snakes are highly specialized organisms. However, despite the constraints imposed by their elongated, limbless body, they have undergone a striking adaptive radiation (Scanlon and Lee, 2011). They constitute, together with the lizards, about 95\% of the living reptiles (McDiarmid et al., 1999). They are the representative of the suborder Ophidia (Serpents) of the order Squamata. About 31 families; 450 living genera and 2600 species of the ophidians are known (McDiarmid et al., 1999). They show a remarkable closer relationship with the lizards than with any other groups of reptiles.

Phylogentically, Young (1981) states that the snakes are of relatively recent appearance and that they are descended from lizards, but their precise mode of origin is obscure. Some workers believe that their nearest living reptiles are the platynoid lizards, Varanids (Schwenk, 1988; Rieppel, 1994; Lee, 1998), others show that the Amphisbaenia and Dibmidae are the sister groups of serpents (Wu et al., 1997; Hallermann, 1998). Moreover, the earliest snake fossils known are from the Cretaceous deposits and seem to be related to boas. Colubrid snakes are first known from the late Oligocene, followed by the venomous snakes elapids and viperids during Miocene (Young, 1981).

Inspite of the importance of the study of the cranial nerves of Ophidia, as a base of Phylogeny and behavioural aspects, yet it is scarce and sporadic. Since the work of Agarwal (1964 \& 1966) on the cranial nerves of Ptyas mucosus, which depends mainly on dissection, the matter remained vague. The first valuable work was that of Hegazy (1976), on the cranial nerves of three ophidians belonging to three different families. Auen and Langebartel (1977) studied the cranial nerves of two colubrid species. Although, this work is useful, yet it is shortly described, poorly illustrated and reasonably accurate. Mostafa (1990) published successive studies on the cranial nerves of 
Spalerosophis diadema. Abdel-Kader et al. (2000) provided a study on the innervation of the nasal region in the Egyptian cobra Naja haje. Omar and Dakrory (2016) present study on the terminal nerve on montpellier snake. The snakes possess a highly developed and unique chemosensory system; comprising the main olfactory organ and the vomeronasal or Jacobson's organ. In Squamata such organs are relatively poorly understood (Rehorek et al., 2000). Most studies, however, have far concentrated on the behavioural and functional aspects (Schwenk, 1993) as well as developmental studies (Kaczmarek et al., 2017); with little attention being given to the innervation of this system (Kratzing, 1975; Wang and Halpern, 1980).

In contrast to Ophidia, the cranial nerves of lizards have been studied in more detail and by many investigators (Soliman and Mostafa, 1984; Soliman et al., 1984; Dakrory, 1994). The last author attempted to show the affinities between Amphisbaenia and Ophidia on one side, and the amphisbaenian and the lizards on the other.

It is clear from the above mentioned historical review that there is an extreme shortage about the ophidian cranial nerves. Consequently, a detailed anatomical study on the anatomy of the sensory cranial nerves of a snake is useful, aiming to throw light on the anatomy of these nerves and to make full analysis for their component fibres and to show the relations between these nerves and the other cranial structures.

\section{Materials and Methods:-}

The material of this study is the snake; Abo-al-ayone, Malpolon moilensis. According to Bernhard (1971) it distributed from North Africa to south western Asia. In Egypt, the Montpellier inhabits western Mediterranean coastal desert, Nile Delta, valley, Siwa oasis and Sinai. It found in the semi-desert, sandy areas of northern Delta, around vegetated salt marshes and in cultivated land. It feeds on small mammals, lizards, Variations in its color include reddish individuals.

Three pregnant females were collected from Baltim city, Kafr El Sheikh Governorate northern coast of Egypt. The fully formed embryos of the snake Malpolon moilensis are carefully removed from the incubated eggs for 15-18 days. The embryos were anesthetized in diethyl ether and the heads of these embryos were cut and fixed in aqueous Bouin's fixative for 24 hours, followed by washing several days with $70 \%$ ethyl alcohol.

The specimens were decalcified using EDTA solution for 50 days with changing the solution every four days. This is followed by washing in $70 \%$ ethyl alcohol for two hours.

Thereafter the heads were treated with ascending series of ethyl alcohol and cleared in xylene followed by embedding in paraffin wax. The heads were cut transversely at thickness $10 \mu \mathrm{m}$ using Reichert microtome. The sections were mounted serially on the microscopic slides followed by staining of the serial sections using haematoxylin - eosin stain. The excess stain was removed by washing with $1 \%$ acid alcohol for two hours.

The serial sections were examined carefully under the microscope to describe the relations of these nerves and other structures in the head region. In order to show the position of the nerves and their relations to the different structures of the head, some serial sections were photomicrographed

\section{Results:-}

\section{N.I Nervus Olfactorius:-}

The nervus olfactorius is a special sensory nerve as it's fibres are not formed by the nervous system elements, but on the other hand, formed by the cells of the sensory olfactory epithelium.

In Malpolon moilensis, the sensory olfactory nerve fibres originating from the sensory olfactory epithelium aggregate into fine branches. These branches extend posteriorly along both the dorsal and medial sides of the olfactory epithelium, within the nasal capsule. As they extend backwards, these branches gradually approach each other and fuse forming many nerve bundles (Fig. 1, N.I). More posteriorly, new olfactory nerve fibers branches are collected from the posterior olfactory epithelium

From the dorsomedial corner of the posterior side of the nasal capsule, the bundles constituting the nervus olfactorius leave the nasal cavity through the foramen olfactorium advehens and directly enter the cranial cavity (Fig. 2, F.OL.AD). Within the cranial cavity, the olfactory nerve bundles extend posteriorly together with those of 
the nervi terminalis-vomeronasalis for a short distance. Then the olfactory nerve bundles enter the main olfactory bulb (Fig. 3, OL.BU, N.I) from its dorsal, lateral and ventral sides.

The nervus olfactorius carries special somatic sensory fibres from the olfactory epithelium.

\section{N.II Nervus Opticus:-}

In Malpolon moilensis, the optic nerve originates from the retinal cells as a stout nerve. This nerve leaves the eyeball through a special foramen in the sclera to enter the orbital region (Fig. 4, N.II). The microscopic examination reveals that the optic sclera is totally fibrous having no sclera bone (Fig. 5, SC). In the orbital region, it extends posteriorly in a medial direction passing dorsal to the ramus inferior of the nervus oculomotorius and the rectus inferior muscle, ventral to the ramus nasalis of the nervus trigeminus and dorsolateral to the trabecula cranii. Thereafter, the nervus opticus passes ventral to the rectus superior muscle, the nervus trochlearis and the ramus nasalis of the nervus trigeminus, medial to the sclera, dorsal to the ramus inferior of the nervus oculomotorius and the rectus inferior muscle and dorsomedial to the lacrimal gland. The nervus opticus enters the cranial cavity through foramen orbitale magnum (Fig. 5, F. OBM).

Intracranially, the nervus opticus of both sides deccusate together forming the optic chiasma (Fig. 5, OP.CH) below the diencephalon, the optic chiasma extends posteriorly in a postion between the rectus superior muscle laterally and the rectus lateralis muscle ventrolaterally. After that, the optic fibres terminate in the roof of the optic lobe of the mesencephalon.

It is clear that the nervus opticus carries special somatic sensory fibres carries impulses from the eye.

\section{N.VIII Nervus Octavus:-}

In Malpolon moilensis the nervus octavus originates from the dorsolateral side of the medulla oblongata by a strong root which lies above and in contact with the root of the nervus facialis (Fig. 6, RO.VIII). After its origin the nervus octavus passes laterally, pierces the pia mater and enters the vestibular ganglion (Fig. 6, G.VE.). This ganglion is, more or less, elongated in the anteroposterior direction. The anterior part of the ganglion lies intracranially and its posterior part located in the foramen acousticum posterius.

From the most anterior end of the vestibular ganglion arises the ramus ampullaries anterior (Fig. 6, R.AMA). This ramus enters the vestibular cavity of the auditory capsule through the foramen acousticum anterius (Fig. 7, F.AA). During its passage through this foramen, this ramus gives rise to a large nerve which extends laterally passing ventral to the utricle and ends in the sensory cells of the crista of the lateral semicircular canal. Thereafter, the main ramus runs anteriorly inside the vestibular cavity giving rise many successive fine branches to the sensory cells of the utricular macula. The remainder of the ramus ampullaris anterior runs anteriorly to the anterior semicircular canal, where it ends as many fibres in the sensory cells of its crista.

Slightly posterior, the vestibular ganglion gives off a branch that enters the auditory capsule through the foramen acousticum. This branch extends posterolaterally ventral to the semicircular canal to terminate in the macula of the sacculus.

More posteriorly, the vestibular ganglion enters the auditory capsule through the foramen acousticum posterius (Fig. 8, F.AP). In this foramen, it gives off a ventral branch to the lagena (Fig. 9, N.LG). Slightly backwards, it gives off another ventral branch to the lagena. Thereafter, the latter ganglion gives off the ramus ampullaris posterior that in the crista of the posterior semicircular canal. The nervus octavus carries special somatic sensory fibres from the inner ear. 


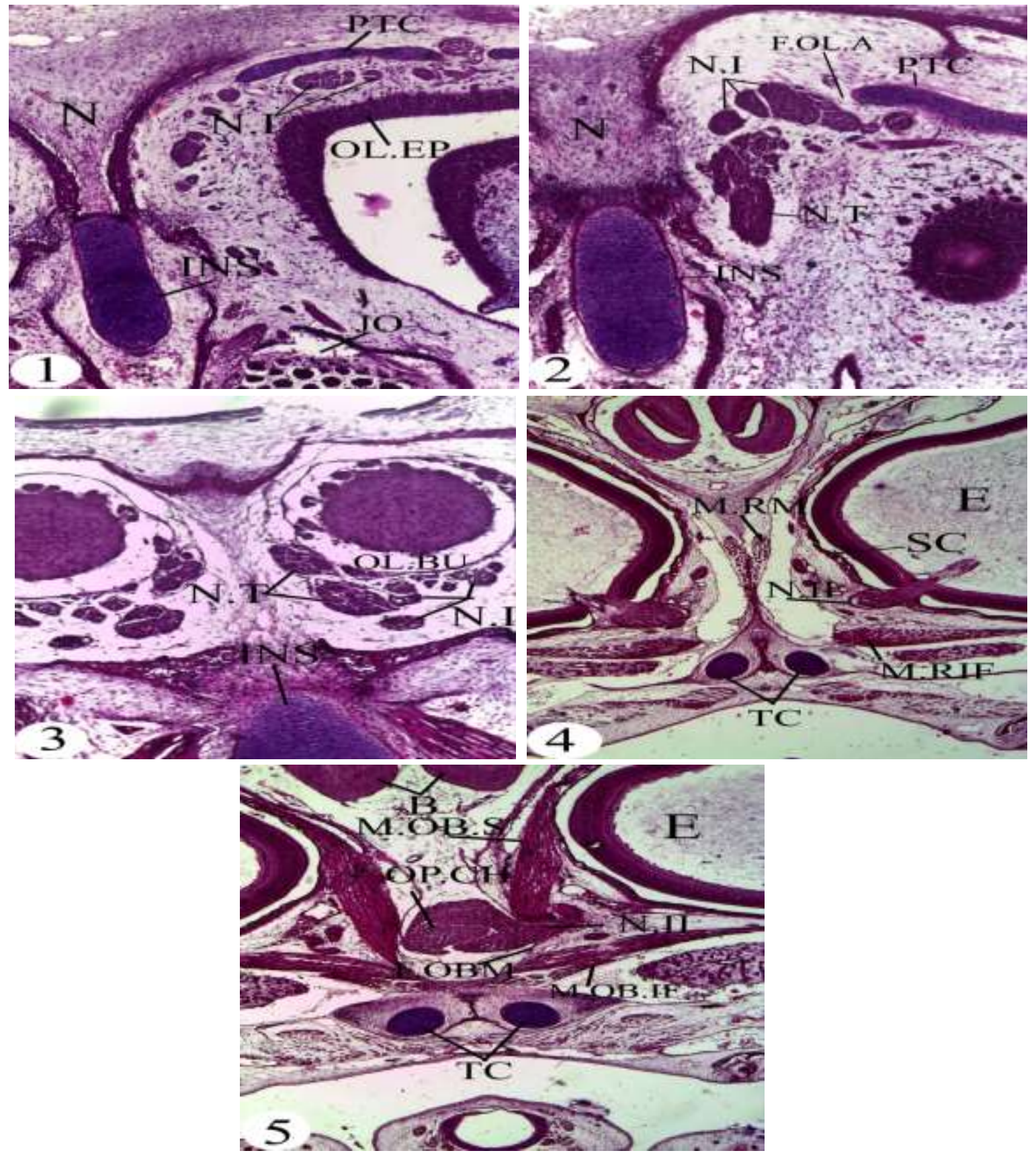

Fig. 1:- A photomicrograph of a part of a transverse section passing through the olfactory region showing the origin of the olfactory nerve from the sensory olfactory epithelium of the olfactory organ.

Fig. 2:- A photomicrograph of a part of a transverse section passing through the olfactory region showing the olfactory nerve bundles and the foramen olfactorium advehens.

Fig. 3:- A Photomicrograph of part of a transverse section passing through the posterior olfactory region showing the entrance of the olfactory nerve to the olfactory bulb.

Fig. 4:- A Photomicrograph of part of a transverse section passing through the orbital region showing the emergence of the optic nerve from the sclera of the eye.

Fig. 5:- A Photomicrograph of part of a transverse section passing through the orbital region showing the optic chiasma.

B: Brain, E: Eye, F.OL.A: Foramen olfactorium advehens, F.OBM: foramin orbital magnum, INS: Internasal septum, JO: Jacopson`s organ, M.OB.IF: Obliqqus inferior muscle, M.OB.S: Obliqqus superior muscle, M.RIF: 
Rectus inferior muscle, M.RM: Rectus medialis muscle, N.I: Olfactory nerve, N.T: Terminal nerve, N: Nasal, OL.BU: Olfactory bulb, Ol.EP: Olfactory epithelium, OP.CH: Optic chaiasma, PTC: Parietotectal cartilage, SC: Sclera, TC: Trapicula cranii.
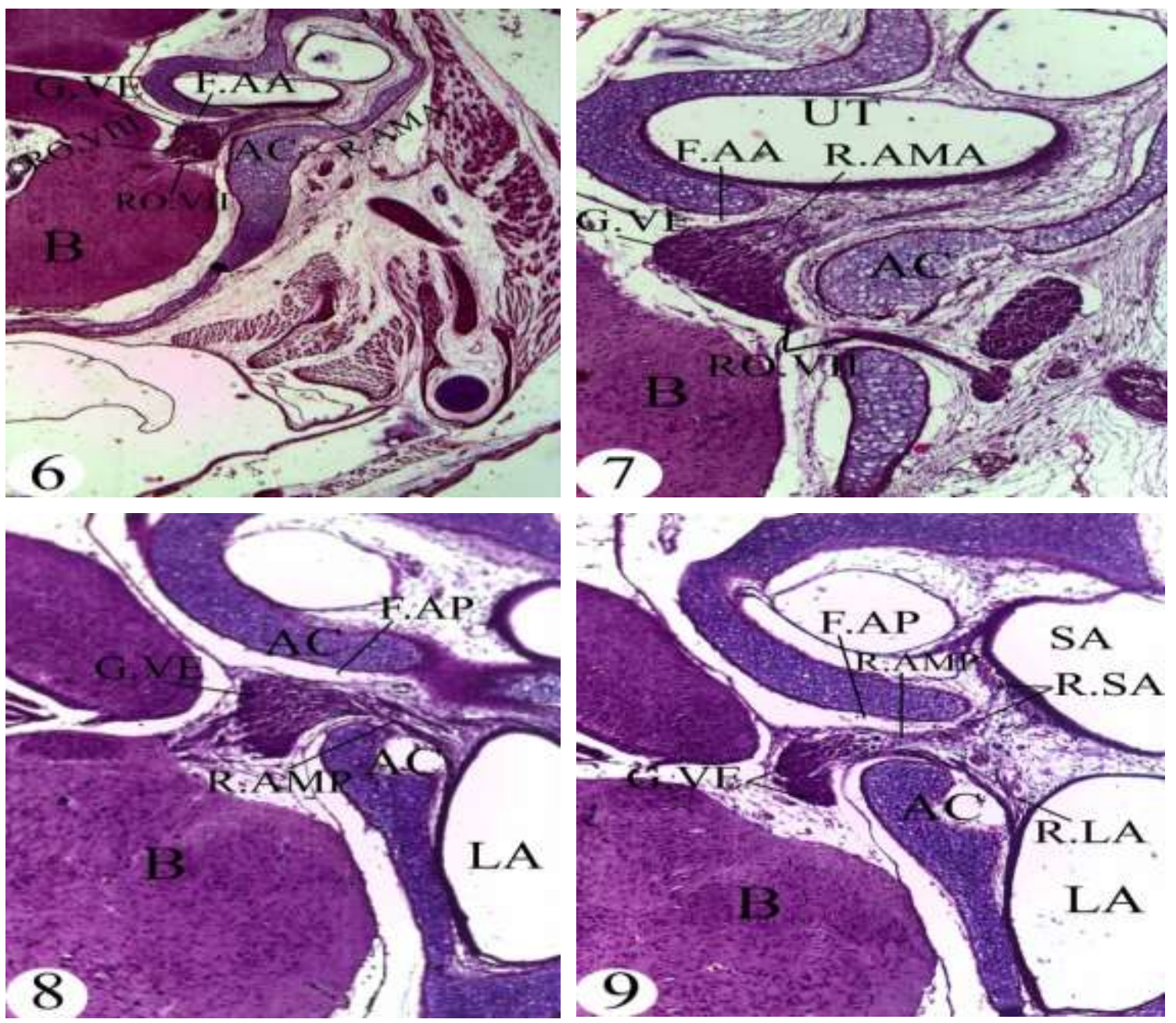

Fig. 6:- A Photomicrograph of a part of a transverse section passing through the otic region showing the root of the nervus octavus, the vestibular ganglion and the ramus ampullaris anterior.

Fig. 7:- A Photomicrograph of a part of a transverse section passing through the otic region showing the foramen acousticum anterior, the ramus ampullaris anterior and the vestibular ganglion.

Fig. 8:- A Photomicrograph of a part of a transverse section passing through the otic region elucidating the position of the posterior portion of the vestibular ganglion in the foramen acousticum posterius.

Fig. 9:- A Photomicrograph of a part of a transverse section passing through the otic region elucidating the nerve to lagena, the nerve to sacula and the ramus ampullaris posterior.

AC: Auditory capsule, B: Brain, F.AA: Foramin acousticus anterior, F.AP: Foramin acousticus posterior, G.VE: Vestibular ganglion, LA: Lagina, R.AMA: Ramus ampularis anterior, R.AMP: Ramus ampularis posterior, R.LA: Laginar ramus, R.SA: Saculus ramus, RO.VII: Root of the facial nerve, RO.VIII: Root of the acoustic nerve, SA: Sacula, UT: Utricle.

\section{Disscution:-}

In Malpolon moilensis under investigation, the nervus olfactorius exit from the cavity of the nasal capsule through the fenstra olfactorium advehens, which is in the form of a wide incissure and not a complete foramen due to the absence of the sphenethmoidal commissure connecting the planum anteorbitale and the nasal septum. This condition is also found in the ophidians Tropidonotus natrix (De Beer, 1937), Causus rhombeatus (Pringle, 1954), Psammophis sibilans (Hegazy, 1976), in Natrix tessellate (El-Ghareeb et al., 2004a) and in Coluber rogersi (Omar, 
2013). On the other hand, there is a closed complete foramen olfactorium advehens due to the fusion of the planum anteorbitale and the nasal septumwas recorded in Vipera aspis (Peyer, 1912), Viperaressellii (Srinivasachar, 1955), Cerastes Vipera (Hegazy, 1976), Naja Haje(Abdel-Kader et al., 2000) and in Echis carinatus (Dakrory and Mahgoub, 2009).

In Lacertilia, a closed fenestra olfactorium advehens is found in the most of the lizards so far described. The only exception is in Agama hispida (Malan, 1946; Barry, 1953), Agama atra (Malan, 1946), Agama stellio (Eyal-Giladi, 1964) and in Laudakia stellio (Shamakh, 2009). In these cases, there are a number of foramina instead of the usual fenestra olfactorium advehens. Moreover, in Sceloporous undulates and Iguana iguana (Malan, 1946) the fenestra olfactorium advehens is divided into two foramina.

On the other hand, in the amphisbeanian Diplometopon zarudnyi fenestra olfactorium advehens is in the form of a wide incisures and not a closed foramen (Dakrory, 1994).

In the majority of birds, the nervus olfactorius emerges from the nasal cavity through a define fenestra olfactorium advehens (Soliman et al., 1986a). However, this nerve gets its exit through undelimited fenestra in Anas boschas (De Beer, 1937), a fissure orbitonasalis in Sternus vulgaris (De Kock, 1955) and Nyctisyrigmus pectoralis (Fourie, 1955) and by means of a canal which completely surrounded by bone in Colius indicus (Schoonees, 1963).

In mammals, the fenestra olfactorium advehens, or fenestra cribrosa, is divided into numerous pores of the cribriform plate (De Beer, 1937; Kanagasuntheram and Kanan, 1964; Jollie, 1968). De Beer (1937) stated that the subdivision of the fenestra is a mammalian character, except in monotremes. In such case, the nervus olfactorius leave the nasal cavity through two separate foramina in the cribriform plate. This was recorded by Mc Cotter (1913) in dog and cat, Johnston (1913) in the pig and Hegazy (1990) in the hedgehog. However, Huber and Gulid (1913) and Mc Cotter (1915), dealing with the rabbit and man, respectively, mentioned that the nervusterminalis passes through the cribriform plate anterior to the exit of the vomeronasal nerve.

In this study, the nervus olfactorius enters sessile olfactory bulb i.e., no peduncle. The same case reported in Leptopyphlops cairi (Dakrory, 2005). On the other hand, the olfactory bulbs lie a considerable distance anterior to the olfactory lobe of the fore brain, to which it is joined by an olfactory peduncle. This appears to be a generalcharacterof squamates (Haller von Hallerstein, 1934; Hegazy, 1976; Dakrory, 1994; Abdel-Kader et al., 2000; El-Ghareeb et al., 2004a; Omar, 2013). In Clelonia, Soliman (1964) found that the olfactory bulbs join directly the cerebral hemisphere.

In the present study, the nervus opticus enters the orbital region by penetrating the fibrous sclera which encases the eyeball. This appears to be a common feature in Ophidia (Underwood, 1970;Hegazy, 1976; Mostafa, 1990b).

Among Lacertilia, the sclera is cartilaginous and invested by sclera ossicles as in Amphisbaena (RochonDuvigneaud, 1943), Trogonophis (Bellairs, 1949) and Mabuya quinquetaeniata (Madboly, 2011), in the burrowed lizards Woeltzkowia (Winckles, 1914) and Anniella (Walls, 1942) and in amphisbeanian Diplometopon zarudnyi (Dakrory, 1994). However, the ossicles were found to be absent in Dibamus (Underwood, 1970).

In the present study, the fibres of the nervus opticus decussate completely to form an optic chiasma. Although decussation of the optic nerve is complete in all vertebrates except mammals, Armstrong (1950) stated that the decussation at the optic chiasma, in Lacertavivipara, is not complete.

Among fishes the optic chiasma with complete decussation is also present, in Dasyatisrafinesque (Chandy, 1955) and in Clariasbatrachus (Dalela and Jain, 1968). The same has been described in Amphibia by Shaheen (1987) in Buforegularis.

In mammals only, about half of the fibres in each optic nerve pass to the opposite side. This is generally called incomplete decussation. Quiring (1950) and Eaton (1951) mentioned that this phenomenon is necessary for mammals having binocular vision.

In this study, the nervus opticus enters the cranial cavity through the foramen orbitale magnum. This foramen also, exits the nervi oculomotorius, trochlearis, abducens and the ramus ophthalmicus profundus of the nervus trigeminus 
outside the cranial cavity. This appears to be a common feature in Ophidia (Hegazy, 1976; El-Ghareeb et al.,2004a). However, this foramen is not equivalent to the optic foramen in lizards, through which the nervus opticus passes. In the majority of lizards except the burrowing types, the optic foramen is delimited conveying the nervus opticus. However, in theburrowing lizards: Acontiasmelearis(Brock, 1941a),Anniellapulchra (Bellairs, 1949) and Agamastellio (Eyal-Giladi, 1964), a discrete optic foramen is missing.

In the majority of birds, the optic nerve enters the cranial cavity, together with the oculomotorius and trochlear nerves through a closed sphenoid fontanella. However such fontanella is absent in birds studied by Cords (1904), in the chick (Bellairs, 1958), in Pyromelana (Engelbrecht, 1958) and in the three birds studied by Soliman et al., (1986a).

Regarding mammals, De Beer (1937) could not find a separate optic foramen in Ornithorhynchusparadoxus. In Manisjavanica, the optic foramen is distinctly delimited (Jollie, 1968).

In the present study, the nervus octavus arises from the medulla oblongata by one stout root dorsal and in contact with the root of the nervus facialis. This appears to be a common character of repriles (Hegazy, 1969 ; Mostafa, 1970 \& 1990b; El-Ghareeb, 1997). In some lizards such as Ptyodactylus annularis (Harfferl, 1921), Varanus monitor (Shrivastava, 1964) and Mabuya quinquetaeniata (Madboly, 2011). This nerve has two rami originating from the vestibular ganglion that is located intracranially with its posterior part in the posterior foramen. This case is present in almost all reptiles so far described. This exception that was described by Auen and Langebartel (1977) in the colubride snakes Elaphe obsolete quadrivittata and Thamnophis ordinoides, where they found that the two rami of the nervus octavus enter the medulla oblongata separately.

In this study, the nervus octavus enters the auditory capsule through two foramina (anterius and posterius). This appears to be a common case in Ophidia (De Beer, 1937; Hegazy, 1976; Auen and Langebartel, 1977; Dakrory and Mahgoub, 2005; Omar, 2013). The same condition was found in the majority of lizard (Hegazy, 1969; Mostafa, 1970 \& 1990b; El-Ghareeb, 1997). In some lizards such as Ptyodactylus annularis (Harfferl, 1921), Varanus monitor (Shrivastava, 1964) and Mabuya quinquetaeniata (Madboly, 2011), a third foramen (foramen acousticum medium) is present.

In Amphibia, the nervus octavus enters the cavity of the auditory capsule through two foramina in Bufo viridis (Soliman and Mostafa, 1984e) and in Bufo regularis (Shaheen, 1987).

In birds, however, the condition is quite different from that found in reptiles. There are five acoustic foramina in Struthio (Frank, 1954; Lang, 1956), Rhea (Müller, 1961) and in Upupa, Passer and Streptopelia (Soliman et al., 1986a). Four foramina were described in Spheniscus (Crompton, 1953), Pyromelana (Engelbrecht, 1958) and Fulica (Til Macke, 1969). On the other hand, De Beer (1937) mentioned that, in birds, as well as in higher mammals, the foramina acoustica anterius and posterius must be known as superius and inferius, respectively, due to the backward rotation of the auditory capsule.

\section{References:-}

1. Abdel-Kader, I.Y.; Soliman, M. A. and Hegazy, R. M. (2000): Innervation of the nasal region of the Egyptian cobra Naja haja haje. J. Egypt. Ger. Soc. Zool., 33: 57-76.

2. Agarwal, P.N. (1966): On the cranial nerves of Ptyas mucosus. Věst. Ćesk Spol. Zool., 3: 185-193.

3. Agarwal, P.N. (1964): The innervation of the eye muscles in Ptyas mucosus.Věst. Cesk Spol. Zool., 2: 164166.

4. Armstrong, J.A. (1950): An experimental study of the visual pathways in a reptile (Lacerta vivipara). J. Anat., 84: 146-167.

5. Auen, E.D. and Langebartel, D.A. (1977): The cranial nerves of the colubrid snakes Elaphe and Thammophis. J. Morph., 154: 205-222.

6. Barry, T.H. (1953): Contributions to the cranial morphology of Agama hispida (Linn.). Ann. Univ. Stellenbosch, 29(A) 2: 55-57.

7. Bast, T.H. (1933): The anatomy of the rhesus monkey (Macaca mulatta): The eye and the ear. Hafner publishing Co., New York.

8. Bellairs, A.d'A. (1949): Observation on the snout of varanus and a comparison with that of other lizards and snakes. Jour. Anat. 83(2):116-146. 
9. Bellairs, A.d'A. (1958): The early development of the interorbital septum and the fate of the anterior orbital cartilage in the birds. J. Embry of Exp. Morph., 6: 68-85.

10. Bernhard, G.(1971):crazaimek's Animal Life Encyclopedia. New York.

11. Brock, G.T. (1941): The skull of Acontias meleagris, with a study of the affinities between lizards and snakes. J. Linn. Soc. (Zool.), 41: 71-88.

12. Chandy, M. (1955): The nervous system of the Indian stingray Dasyatis rafinesque (Trygon Cuvier). Journ. Zool. Sci. India 7: 1-12.

13. Cords, E. (1904): Beiträge zur Lehre vom Kopfnerven-system der Vöggel. Anat. Hefte., 26: 49-100.

14. Crompton, A.W. (1953): The development of the chondrocranium of Spheniscus demersus with special reference to the columella auris of birds. Acta Zool. (Stockh.), 34: 71-146.

15. Dakrory, A.I. (1994): Anatomical studies on the cranial nerves of the Amphisbaenian (Diplometopon zarudnyi). M.Sc.Thesis, Fac. Sci. Cairo univ., Egypt.

16. Dakrory, A.I. (2005): The innervation of the olfactory apparatus of the bird snake Leptotyphlops cairi (Dumeril and Bibron, 1844). Egypt. J. Zool., 45: 201-214.

17. Dakrory, A.I. and Mahgoub, A.F. (2005): The cranial nerves of the snake Natrix tessellata (Ophidia, Colubridae): The nervus trigeminus. J. Egypt. Ger. Soc. Zool., 46(B): 17-59.

18. Dakrory, A.I. and Mahgoub, A.F. (2009): Innervation of the olfactory apparatus of Echis carinatus (Ophidia: Viperidae). Egypt. J. Zool., 53: 535-551.

19. Dalela, R.C. and Jain, D.K. (1968): Studies on the cranial nerves of Clarias batrachus (Lin.). Agra Univ. Journ. Res., 17: 107-114.

20. De Beer, G.R. (1937): Development of the vertebrate skull. Clarendon Press, Oxford.

21. De Kock, J. M. (1955): The cranial morphology of Sturnus vulgaris Linnaeus. Ann. Univ. Stellenbosch, 31 (A) 3: 153-177.

22. Eaton, H.T. (1951): The comparative anatomy of the vertebrates. New York.

23. El-Ghareeb, A.A. (1997): Anatomical studies on the cranial nerves of the lizard Acanthodactylus boskianus (Daud). Ph. D. Thesis, Fac. Sci., Cairo Univ., Egypt.

24. El-Ghareeb, A.A.; Abdel-Kader, I.Y. and Mahgoub, A.F. (2004): The cranial nerves of the snake Natrix tessellata (Ophidia, Colubridae). The nervi terminalis, olfactorius, opticus and octavus. Egypt. J. Zool. 43:309332.

25. Engelbrecht, D. van Z. (1958): The development of the chondrocranium of Pyromelana orix orix. Acta Zool., 39: 115-199.

26. Eyal-Giladi, H. (1964): The development of the chondrocranium of Agama stellio. Acta Zool., 45: 139-165.

27. Fourie, S. (1955): A contribution to the cranial morphology of Nyctisyrigmus pectoralis with special reference to the palate and cranial kinesis. Ann. Univ. Sellenbosch, 31(A)4: 178-215.

28. Frank, G.H. (1954): The development of the chondrocranium of the ostrich. Ann. Univ. Stellenbosch, 30 (A) 4: $179-248$.

29. Hafferl, A. (1921): Das knorpelige Neurocranium des Gecko (Platydactylus annularis). Z. Anat. Entw. Gesch., 62: 433-518.

30. Haller von Hallerstein, V. (1934): Anatomie der Wirbeltiere 2/1, herausgegeben von Bolk, Göppert, Kallius, Lubosch. Berlin und Wien.

31. Hallerma, J., 1998: The ethmoidal region of Dibamus taylon' (Squamata: Dibamidae), with a phylogenetic hypothesis on dibamid relationships within Squamata, Zoological Joumal of Linnean Society, 122: 385426.

32. Hegazy, M.A. (1969): The cranial nerves of Chalcides ocellatus. M. Sc. Thesis, Fac. Sci., Cairo Univ., Egypt.

33. Hegazy, M.A. (1976): Comparative anatomical studies on the cranial nerves of Ophidia. Ph.D. Thesis, Faculty of science, Cairo University, Egypt.

34. Hegazy, M.A. (1990): A contribution to the Anatomy of the vomeronasal organ of Jacobson of Mammals with special reference to the Insectivore Hemiechinus auritus (Gmelin). Proc. Zool. Soc. A.R. E., 19: 33-50.

35. Huber, G.C. and Guild, S.R. (1913): Observations on the peripheral distribution of the nervus terminalis in Mammalia. Acta Rec., 7: 253-272.

36. Johnston, J.B. (1913): Nervus terminalis in reptiles and mammals. J. Comp. Neurol., 23 (2): 97-120.

37. Jollie, M.T. (1968): The head skeleton of a new-born Manis javanica with comments on the ontogony and phylogeny of the mammal head skeleton. Acta Zool., 49: 227-305.

38. Kaczmarek,P; Hermyt, M. and Rupik, W. (2017): Embryology of the VNO and associated structures in the grass snake Natrix natrix (Squamata: Natricinae): a 3D perspective. Frontiers in Zool., 14: 1-26. 
39. Kanagasuntheram, R. and Kanan C.V. (1964): The chondrocranium of a $19 \mathrm{~mm}$ C.R. length embryo of Galago senegalensis senegalensis. Acta Zool., 45: 107-121.

40. Kratzing, J.E. (1975). The fine structure of the olfactory and vomeronasal organs of a lizard (Tiliqua scincoides scincoides). Cell and Tissue Research 156, 239-252.

41. Lang, C.T. (1956): Das Cranium der Ratiten mit besonder Berücksichtigung von Struthio camelus. Z.F. W. Zool., 159: 165-224.

42. Lee, M.S.Y. (1998). Convergent evolution and character correlation in burrowing reptiles. Towards a resolution of squamate relationships. Bid. J. Linn. Soc., 65: 369-453.

43. Madboly, N.M. (2011): Anatomical studies on the cranial nerves of Mabuya quinquetaeniata. B.Sc. thesis, Zool. Dep., Fac. Sci., Helwan Univ., Egypt.

44. Malan, M.E. (1946): Contributions to a comparative anatomy of the nasal capsule and organ of Jacobson of Lacertilia. Ann. Univ. Stellenbosch, 24(A) 4: 69-137.

45. Mc Cotter, R.E. (1913): The nervus terminalis in the adult dog and cat. J. Comp. Neurol., 23 (2): 145-152.

46. Mc Cotter, R.E. (1915): A note on the course and distribution of the nervus

47. McDiarmid, R.W.; Campbell, J.A. and Toure, T., 1999: Snake species of the world: A taxonomic and geographic reference. v. 1,Herpetologists' League, Washington, DC, USA; xi, 511.

48. Mostafa, R. H. (1990): On the main special sensory nerves Olfactorius, Opticus and Acusticus in Uromastyx agypticus microlepis (Blanford). Egypt J. Anat., 13 (2): 247-258.

49. Mostafa, R.H. (1970): A detailed study on the cranial nerves of the gecko Tarentola mauritanica Linn. M.Sc. Thesis, Fac. Sci., Cairo Univ., Egypt.

50. Müller, H.J. (1961): Die Morphologie und Entwicklung des Cranium von Rhea Americana Linne. I. Das Knoepellige Neurocranium. Z. F. W. Zool., 165(3-4): 221-319.

51. Olivier, R., 1994: Studies on Skeleton Formation in Reptiles. Patterns of Ossification in the Skeleton of Lacerta agilis exigua Eichwald (Reptilia, Squamata), Journal of Herpetology, 28, (2): 145-153.

52. Omar, A.R. (2013): Anatomical Studies on the Cranial Nerves of the Snake Coluber rogersi. Ph.D. Thesis, Zool.Dep., Fac. Sci., Cairo Univ., Egypt.

53. Omar, A.R. and Dakrory, A.I. (2016): The Terminal and Vomeronasal Nerves of Montpellier Snake, Malpolon monspessulana (Colubridae, Ophidia, Squamata). Vestnik zoologii, 50(2): 179-184.

54. Peyer, B. (1912): Die Entwicklung des Schädelskelettes von Vipera aspis. J. Morph., 44: 563-621.

55. Pringle, J.A. (1954): The cranial development of certain south African snakes and the relationship of this group. Proc. Zool. Soc. London, 123: 813-865.

56. Quiring, D.P. (1950): Functional anatomy of the vertebrates. $1^{\text {st }}$ Ed. New York, Toronto, London. Ms. GrawHill Book Company, Inc. PP. 239-249.

57. Rehorek S.J.; Firth, B.T. and Hutchinson, M.N. (2000): Can an orbital gland function in the vomeronasal sense? A study of the pygopodid Harderian gland. Canadian Journal of Zoology 78(4): 648-654.

58. Rochon-Duvigneaud (1943): Angel and Rocon- Duvigneaud in Rocon- Duvigneaud (1943). Quoted by Underwood "Biology of the Reptilia", 2: 1-97, Academic press, London and New York.

59. Scanlon, J. D., and Lee, M. S. Y. (2011). The major clades of living snakes: morphological evolution, molecular phylogeny, and divergence dates. In 'Reproductive Biology and Phylogeny of Snakes'. (Eds D. M. Sever and R. D. Aldridge.) pp. 55-95. (Science Publishers, Inc.: Enfield, NH.)

60. Schoonees (1963): Some aspects of the cranial morphology of Colius indicus. Ann. Univ. Stellenbosch, 38: 215-246.

61. Schwenk, K. (1993). The evolution of chemoreception in squamate reptiles: A phylogenetic approach. Brain Rev. Evol., 42: 124-137.

62. Schwenk, K., 1988: Comparative morphology of the lepidosaue tongue and its relevance to Squamate phylogeny, Phylogenetic Relationships of the Lizard Families, Stanford Univ. Press. Stanford. pp: 569-598.

63. Shaheen, A.A. (1987): Anatomical studies on the cranial nerves of Bufo regularis Reuss. M. Sc. Thesis, ElMinia University.

64. Shamakh, A.A. (2009): Innervation of the olfactory apparatus of Laudakia stellio (Reptilia - Squamata Agamidae). Egypt. J. Zool., 52: 453-469.

65. Shrivastava, R.K. (1964): The structure and the development of the chondrocranium of Varanus. III. The Otic and Occipital region, Basal plate, Viscero-cranium and certain features of the osteocranium of a juvenile. J. Morph., 106(2): 147-187.

66. Soliman, M.A. (1964): Die Kopfnerven der Schildkröten. Z. F. W. Zool., 169: 215-312. 
67. Soliman, M.A. and Mostafa, R.H. (1984): The cranial nerves of Bufo viridis (LAUR). The nervi Facialis, Acusticus, Glossopharyngeus and vagus. Bull. Fac. Sci. Cairo Univ., 52: 461-493.

68. Soliman, M.A.; Hegazy, M.A.; Mokhtar, F.M. and Mostafa, R.H. (1986): The cranial nerves of Birds. I. the main special sensory nerves, nervus olfactorius, nervus opticus and nervus octavus. Proc. Zool. Soc. A.R.E., 10: 211-232.

69. Soliman, M.A.; Mostafa, R.H. and Abdel-Kader, I.Y. (1984): Anatomical studies on the cranial nerves of Agama pallida (Reuss). II. The nervus trigeminus. Egypt. J. Anat., 8: 159-190.

70. Srinivasachar, H.R. (1955): Observations on the development of the chondrocranium in Vipera. Anat. Anz., 101: 219-225.

71. Til Macke (1969): Die Entwicklung des Cranium von Fulica atra. J. Morph., 113, 2: 229-294.

72. Underwood, G. (1970): The eye. In C. Gans and T.S. Parsons (Eds.), Biology of the Reptilia. Academic Press, London and New York, pp. 1-97.

73. Walls, G.L. (1942): The vertebrate eye and its adaptive radiation. Bull. Cranbrook Inst. Sci., 19: 1-185.

74. Wang, R.T. and Halpern, M. (1980): Light and electron microscopic observations on the normal structure of the vomeronasal organ of garter snakes. J. Morphol., 164, 47-67.

75. Winckles, A. (1914): Das Auge von Voeltzkowia mira. Ph.D. Thesis, Universität Bonn.

76. Wu, X.C.; Brinkman, D.B. and Russell, A.R. (1997). Sineoamphisbaena hexatabularis, an amphisbaenian (Diapsida: Squamata) from the Upper Cretaceous redbeds at Bayan Mandahu (Inner Mongolia, People's Republic of China), and comments on the phylogenetic relationships of the Amphisbaenia. Can. J. Earth. Sci., 33: 541-577.

77. Young, J.Z. (1981): The life of vertebrates. $2^{\text {nd }}$ ed. Oxford Univ.Pres.New York and Oxford. 